\title{
MODELING AND SIMULATION OF RELIEF INFLUENCE ON EUCALYPTUS FORESTS: INTERACTION BETWEEN SOLAR IRRADIANCE AND PRODUCTIVITY ${ }^{1}$
}

\author{
Yhasmin Paiva Rody ${ }^{2}$, Aristides Ribeiro ${ }^{3 *}$, Aline Santana de Oliveira ${ }^{4}$ and Fernando Palha Leite ${ }^{5}$
}

\footnotetext{
${ }^{1}$ Received on 02.09.2014 accepted for publication on 01.12.2015.

${ }^{2}$ Fibria Celulose, Centro de Tecnologia. - Jacareí, SP - Brasil. E-mail: <yhasmin.rody@fibria.com.br>.

${ }^{3}$ Universidade Federal de Viçosa, Departamento de Engenharia Agrícola, Viçosa, MG - Brasil. E-mail: <ribeiro@ufv.br>.

${ }^{4}$ Universidade Federal de Viçosa, Programa de Pós-Graduação em Meteorologia Agrícola, Viçosa, MG, Brasil. E-mail:

<alinesantolive@yahoo.com.br>.

${ }^{5}$ Celulose Nipo Brasileira S. A, Belo Oriente, MG - Brasil. E-mail: < fernando.leite@cenibra.com.br>.

${ }^{*}$ Corresponding author.
}

\begin{abstract}
This study aimed to verify the differences in radiation intensity as a function of distinct relief exposure surfaces and to quantify these effects on the leaf area index (LAI) and other variables expressing eucalyptus forest productivity for simulations in a process-based growth model. The study was carried out at two contrasting edaphoclimatic locations in the Rio Doce basin in Minas Gerais, Brazil. Two stands with 32-year-old plantations were used, allocating fixed plots in locations with northern and southern exposure surfaces. The meteorological data were obtained from two automated weather stations located near the study sites. Solar radiation was corrected for terrain inclination and exposure surfaces, as it is measured based on the plane, perpendicularly to the vertical location. The LAI values collected in the field were used. For the comparative simulations in productivity variation, the mechanistic 3PG model was used, considering the relief exposure surfaces. It was verified that during most of the year, the southern surfaces showed lower availability of incident solar radiation, resulting in up to $66 \%$ losses, compared to the same surface considered plane, probably related to its geographical location and higher declivity. Higher values were obtained for the plantings located on the northern surface for the variables LAI, volume and mean annual wood increase, with this tendency being repeated in the $3 \mathrm{PG}$ model simulations.
\end{abstract}

Keywords: Terrain exposure surfaces; LAI; Global solar radiation.

\section{MODELAGEM E SIMULAÇÃO DA INFLUÊNCIA DO RELEVO EM FLORESTAS DE EUCALIPTO: INTERAÇÃO ENTRE A IRRADIÂNCIA SOLAR E PRODUTIVIDADE}

\begin{abstract}
RESUMO - Este trabalho teve por objetivo verificar as diferenças da intensidade da radiação frente às distintas faces de exposição do relevo e quantificar estes efeitos no índice de área foliar (IAF) e outras variáveis que expressam a produtividade de florestas de eucalipto, para simulações em um modelo de crescimento de plantios florestais. O estudo foi realizado em duas localidades de contrastes edafoclimáticos, localizadas na bacia do Rio Doce, MG. Trabalhou-se em dois talhões com plantios em idades de 32 meses, tendo sido alocadas parcelas fixas em locais com a face de exposição norte e sul. Os dados meteorológicos foram obtidos de duas estações meteorológicas automáticas localizadas próximas às localidades de estudo. A radiação solar foi corrigida em função das inclinações efaces de exposição do terreno, tendo em vista que esta é mensurada no plano, perpendicularmente à vertical do local. Foram utilizados os valores do IAF coletados em campo. Para as simulações comparativas na variação da produtividade, utilizou-se o modelo mecanístico $3 P G$ considerando as faces de exposição do relevo. Verificou-se que na maior parte do ano, as faces sul apresentaram menor disponibilidade de radiação solar incidente resultando em perdas de até $66 \%$ em comparação à mesma superfície considerada plana, podendo
\end{abstract}


estar relacionada à localização geográfica e maior declividade do terreno nessa face de exposição. Maiores valores foram obtidos para os plantios localizados na face norte nas variáveis IAF, volume e incremento médio anual de madeira. Esta tendência se repetiu nas simulações do modelo $3 P G$.

Palavras-Chave: Faces de exposição do terreno; IAF; Radiação solar global.

\section{INTRODUCTION}

Solar radiation plays an important role in forest distribution, composition, and productivity. It is responsible for the excitation of chlorophyll molecules in the photo-synthetically active spectrum $(0.40$ to 0.70 $\mu \mathrm{m}$ ), and allows the production of carbohydrates through photosynthesis.

Relief modifies the radiation regime according to the exposure surface and declivity degree of the terrain, promoting an increase or decrease of the energy available for biosynthesis, altering the energy balance and local microclimate. Few studies have been conducted considering that relief can lead to error estimates in solar radiation balance (MEFTI et al., 2003; FACCO et al, 2009).

Topographical influences are recognized in floristic composition, i.e., in the distribution of forest species (CARVALHO et al., 2005), productivity (SOUZA et al. 2006), and degree of forest fire risks (SHERMAN et al., 2008). Sariyildiz and Kucuk (2005) showed that exposure surface and declivity affect soil chemistry, litter quality, and nutrient cycling. Based on the differences found in the soils examined in the northern and southern surfaces, Sidari et al., (2008) suggest that new microclimates are generated, significantly influencing clay content, organic matter, and enzyme activities, factors responsible for soil fertility which can lead to change in biomass incorporation by the plants, thus influencing production.

Watson (1947) defined LAI as the integrated leaf area of the canopy per surface unit projected onto soil. Variation in the intensity and duration of incident radiation, under the relief conditions assessed, may generate different canopy LAI responses, showing the importance of this quantification. The plant should be efficient in capturing radiation, which depends on the structure of the canopy, with LAI being a parameter that evaluates this potential use of photosynthetic energy.

Accurate crop growth forecasts are important when estimating the yield potential of wood products, as well as investigating the environmental effects on crops.
Process-based models (PBM) simulate the growth patterns of trees in terms of biophysical mechanisms in response to environmental conditions and management practices. These models can accurately predict growth rate estimates, in short rotation; quantify climate influence on productivity; and estimate the productive potential in areas where forest plantations are not well developed.

The 3PG model (Physiological Principles in Predicting Growth) developed by Landsberg and Waring (1997) is a PBM that estimates forest productivity based essentially on the amount of radiant energy absorbed by the canopy, converted and allocated to the various components of the tree, such as leaves, wood, and roots. It is a generalized model for nonspecific stands, applicable to homogeneous forest plantations, such as eucalyptus plantations (PAUL et al., 2007, RODRIGUEZ et al, 2009;ALMEIDA et al, 2010 ; BAESSO et al, 2010; SILVA et al., 2013; VEGA-NIEVA et al., 2013)..

This study aimed to verify the differences in radiation intensity under distinct relief exposure surface conditions, as well as to quantify these effects on LAI and other variables that express eucalyptus forest productivity, for simulations in a forest plantation growth model in the Rio Doce basin, in Minas Gerais.

\section{MATERIALS AND METHODS}

\subsection{Study area}

This study was conducted in clonal eucalyptus forest plantations owned by Celulose Nipo-Brasileira $\mathrm{S} / \mathrm{A}$ (CENIBRA) in the Rio Doce basin, $\mathrm{MG}$, in two stands in distinct physiographic locations (Table 1) : Antônio Dias (AD), and Belo Oriente (BO). According to the Köppen classification, AD climate was characterized as of the Cwa - humid subtropical type, with dry winters, and $\mathrm{BO}$ climate as of $\mathrm{Aw}$ - rainy tropical savannah type, with dry winters and maximum summer rainfalls (SOUZA et al., 2006).

Since the two locations have different altitudes, and thus, distinct weather conditions, different genetic materials were used, expressing the potential 
Table 1 - Description of plantation plots in the northern (N) and southern (S) exposure surfaces. Tabela 1 - Descrição dos talhões de plantio nas faces de exposição norte (N) e sul (S).

\begin{tabular}{|c|c|c|c|c|c|c|c|}
\hline \multirow[t]{2}{*}{ Location } & \multirow[t]{2}{*}{ Area (ha) } & \multicolumn{2}{|c|}{$\begin{array}{c}\text { Geographic } \\
\text { coordinates }\left({ }^{\circ}\right)\end{array}$} & \multirow[t]{2}{*}{$\begin{array}{l}\text { Exposure } \\
\text { surfaces }\end{array}$} & \multirow[t]{2}{*}{$\begin{array}{l}\text { Altitude } \\
\text { (m) }\end{array}$} & \multirow[t]{2}{*}{$\begin{array}{l}\text { Azimuth } \\
\left(^{\circ}\right)\end{array}$} & \multirow[t]{2}{*}{$\begin{array}{c}\text { Mean } \\
\text { declivity }\left(^{\circ}\right)\end{array}$} \\
\hline & & Latitude & $\overline{\text { Longitude }}$ & & & & \\
\hline \multirow{2}{*}{ Antônio Dias (AD) } & 74 & $19.47 \mathrm{~S}$ & $42.79 \mathrm{O}$ & $\mathrm{N}$ & 916 & 350 & 11 \\
\hline & & $19.47 \mathrm{~S}$ & $42.79 \mathrm{O}$ & $\mathrm{S}$ & 961 & 196 & 18 \\
\hline \multirow{2}{*}{ Belo Oriente (BO) } & 77 & $19.30 \mathrm{~S}$ & $41.42 \mathrm{O}$ & $\mathrm{N}$ & 230 & 352 & 12 \\
\hline & & $19.29 \mathrm{~S}$ & $42.42 \mathrm{O}$ & $\mathrm{S}$ & 251 & 168 & 31 \\
\hline
\end{tabular}

productivity of the stands being selected, Thirtytwo year old Eucalyptus grandis $\mathrm{x}$ E. urophylla hybrids were used.

Four fixed $30 \times 30 \mathrm{~m}$ plots were allocated in each of the two stands at slope sites with northern and southern exposure surfaces. No less than 35 planting lines of the field boundary were kept to prevent outside external interferences.

Soil standardization in the plots was carried out, with Acric Red-Yellow Latosol (Oxisol) being present in both plantings.

\subsection{Meteorological data}

Meteorological data were obtained from two automated stations, installed less than $10 \mathrm{~km}$ from the stands, in each of the study areas. The geographical coordinates of the station located in AD were $19^{\circ} 29^{\prime} 19$ "S latitude, $42^{\circ} 51^{\prime}$ '54' $O$ in length and $1273 \mathrm{~m}$ altitude. In $\mathrm{BO}$, geographical coordinates were $19^{\circ} 18^{\prime} 50$ " $\mathrm{S}$ latitude, $42^{\circ} 23^{\prime} 38^{\prime \prime} \mathrm{O}$ longitude, and 240 meters. Monthly averages from hourly data measured by sensors were used from the beginning of planting in July 2006 until January 2009.

The meteorological variables temperature and air humidity (model HMP45C Vaisala), global solar radiation (Kipp and Zonen - SP LITE), rainfall (model TB3 CS700L1, Hydrological Services) and wind speed (model 03001 5) were also used in this study.

For environmental characterization, water balance was calculated based on the mean monthly rainfall data and reference evapotranspiration estimated by the Penman-Monteith equation (1965), parameterized by the Food and Agricultural Organization (FAO), which includes aerodynamic components and energy balance.

Eto $=\frac{0,408 \Delta(R n-G)+\gamma \frac{900}{(T+273)} U_{2}\left(e_{s}-e_{a}\right)}{\Delta+\gamma\left(1+0,34 U_{2}\right)}$ where: Eto $=$ reference evapotranspiration $(\mathrm{mm}$ day $\left.^{-1}\right) ; \ddot{A}=$ declivity of the vapor pressure curve $\left(\mathrm{kPa}{ }^{\circ} \mathrm{C}^{-1}\right) ; \mathrm{Rn}=$ net radiation $\left(\mathrm{MJ} \mathrm{m}^{-2} \mathrm{~h}^{-1}\right) ; \mathrm{G}=$ soil heat flux $\left(\mathrm{MJ} \mathrm{m}^{-2} \mathrm{~h}^{-1}\right)$; a psychometric constant $\left(\mathrm{kPa}^{\circ} \mathrm{C}^{-1}\right) ; \mathrm{T}=$ air temperature $(\mathrm{K}) ; \mathrm{U}_{2}=$ wind speed at $2 \mathrm{~m}$ height $\left(\mathrm{m} \mathrm{s}^{-1}\right) ; \mathrm{e}_{\mathrm{s}}=$ water vapor saturation pressure $(\mathrm{kPa}) ; \mathrm{e}_{\mathrm{a}}=$ actual water vapor pressure. According to FAO, soil heat flux can be considered null when computed using a daily time scale. The equations used to calculate other variables in Equation 1 are shown in Allen et al. (1998).

Available water capacity (AWC) of $150 \mathrm{~mm}$ was adopted, suitable for the soil type and population studied.

Figure 1 shows the mean values of water balance, temperature, and global radiation, indicating the differences between the two areas where the stands are located. Lower water availability was verified in $\mathrm{BO}$, located at a lower altitude (Figure 1b), with higher water deficit $(208.2 \mathrm{~mm})$ than $\mathrm{AD}(93.7 \mathrm{~mm})$ and higher mean temperature. There was a mean reduction of $8.5 \%$ of global radiation in $\mathrm{AD}$, compared to $\mathrm{BO}$, due to increased cloudiness, likely the result of orographic effects.

\subsection{Correction of solar radiation on inclined surfaces}

Correction of radiation on inclined surfaces was carried out by the equation below, proposed by Iqbal (1979):

$$
\begin{aligned}
& R g i=\left(I_{n} \operatorname{Cos} \theta\right)+\left(I_{d} \operatorname{Cos}\left(\frac{i}{2}\right) \operatorname{Cos}\left(\frac{i}{2}\right)\right)+ \\
& \left(\left(I_{n} \operatorname{Cos} Z+I_{d}\right) \alpha \operatorname{sen}\left(\frac{i}{2}\right) \operatorname{sen}\left(\frac{i}{2}\right)\right)
\end{aligned}
$$

where: $\mathrm{Rgi}=$ corrected incident global solar irradiance (diffuse and direct) $\left(\mathrm{MJm}^{-2} \mathrm{~h}^{-1}\right) ; I_{\mathrm{n}}$ : normal direct solar radiation at the surface (corrected direct); $I_{\mathrm{d}}=$ diffuse solar radiation on a plane surface

Revista Árvore, Viçosa-MG, v.40, n.2, p.319-327, 2016

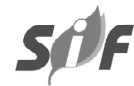




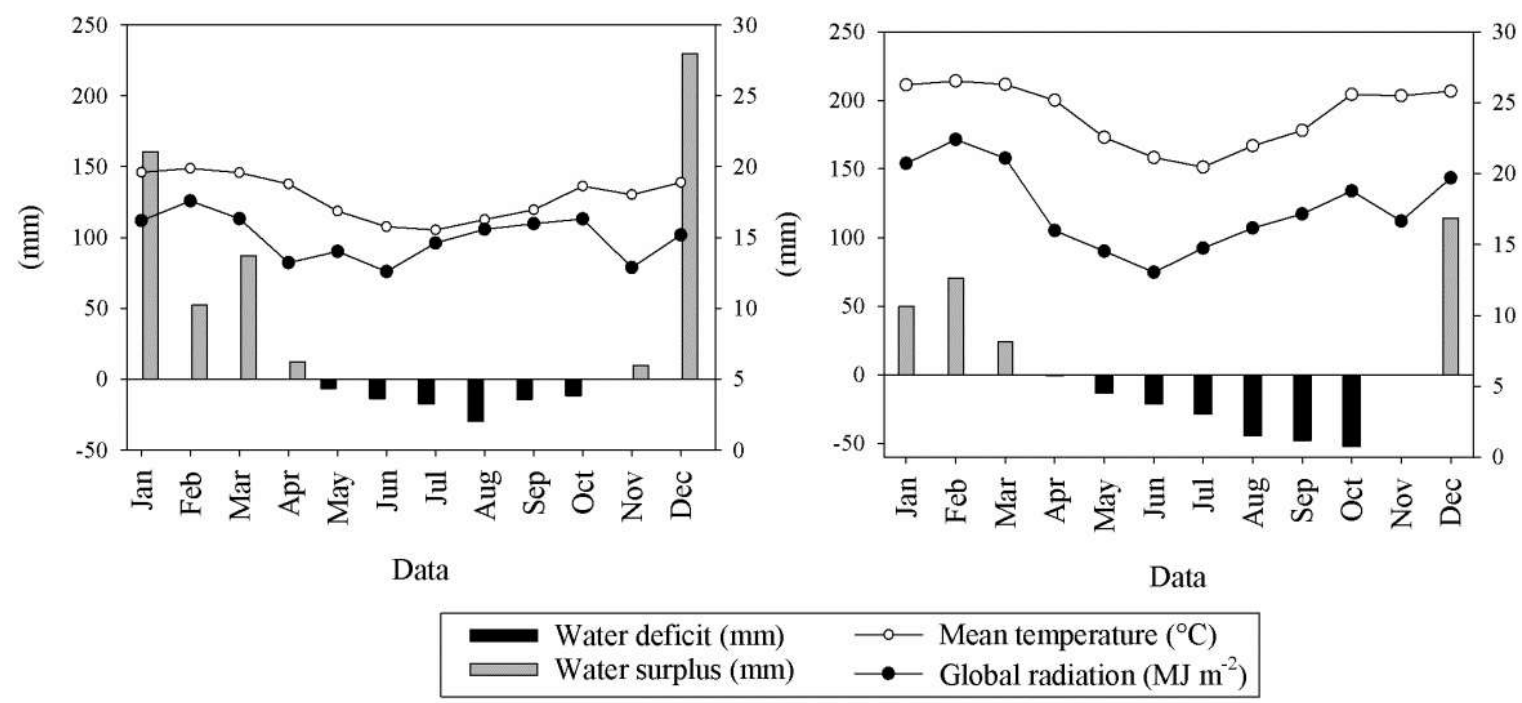

Figure 1 - Climatic characterization of the study locations: monthly total of water balance components, monthly mean temperatures, and monthly mean solar radiation data: (a) Antonio Dias - AD and (b) and Belo Oriente - BO.

Figura 1 - Caracterização climática dos locais de estudo: totais mensais dos componentes do balanço hídrico e médias mensais dos dados de temperaturas e radiação solar média mensal em: (a) Antônio dias - AD e (b) e Belo Oriente - BO.

$\left(\mathrm{MJ} \mathrm{m}^{-2} \mathrm{~h}^{-1}\right)$; ̀̀ = angle of incidence of direct sunlight beams (degrees); $\mathrm{i}=$ surface slope; $\mathrm{Z}=$ zenith angle (degrees); á = reflectance coefficient.

$I_{\mathrm{n}}$ was calculated using equation 3 .

$I_{n}=\frac{I_{d}}{\operatorname{Cos}(z)}$

where $I_{\mathrm{d}}=$ direct radiation on surface perpendicular to the solar beams $\left(\mathrm{MJm}^{-2} \mathrm{~h}^{-1}\right)$ and $\mathrm{z}=$ zenith angle (degrees). The inter-annual variations of the astronomical relations were disregarded on the grounds that their influence is reduced when the models used are considered.

The vertical angle of direct sunlight incidence (q) was estimated using equations 4 to 7 , in which $\mathrm{h}$ is the hourly angle (degrees); and A, B, and C are the equation simplification parameters (IQBAL, 1979).

$$
\begin{aligned}
& \operatorname{Cos}(\theta)=A \operatorname{Cos}(h)+B \operatorname{Sen}(h)+C \\
& A=\operatorname{Cos}(\varphi) \operatorname{Cos}(\delta) \operatorname{Cos}(i)+\operatorname{Sen}(i) \operatorname{Cos}(A z) \operatorname{Cos}(\delta) \operatorname{Sen}(\varphi) \\
& B=\operatorname{Sen}(i) \operatorname{Cos}(\delta) \operatorname{Sen}(a) \\
& C=\operatorname{Sen}(\varphi) \operatorname{Sen}(\delta) \operatorname{Cos}(i)-\operatorname{Sen}(i) \operatorname{Cos}(A z) \operatorname{Sen}(\delta) \operatorname{Cos}(\varphi)
\end{aligned}
$$

The hourly diffuse solar radiation was estimated by the mathematical model proposed by Lima (1996), designed for areas in southeastern Minas Gerais. This model is a combination of equations considering different ranges of the global radiation ratio and radiation at the top of the atmosphere.

\subsection{LAI and forest inventory data}

A LAI-2000 equipment(LI-COR) was used to collect the LAI data. It was operated in the remote mode, using two devices performing simultaneous measurements, with a fixed control unit being installed in open areas and other movable unit for measurements below the canopy. Five LAI mean values were obtained per plot, each being calculated based on five measurements along the planting spacing.

Height and diameter at breast height (DBH) were obtained from the inventory data carried out in all the plots of the stands under study. Volume was calculated using the biometric model (equation 8) with coefficients adjusted to the company's specifications and the mean annual increment (MAI) by equation 9 .

$\operatorname{Ln} V=\beta_{0}+\beta_{1} \operatorname{LnDAP}+\beta_{2} \operatorname{Ln} H+\varepsilon$ 
where: $\mathrm{V}=$ tree volume $\left(\mathrm{m}^{3}\right) ; \beta_{0}, \beta_{1}, \beta_{2}=$ coefficients for each location studied; DAP = diameter at breast height $(\mathrm{cm}) ; \mathrm{H}=$ tree height $(\mathrm{m})$; and $\varepsilon=$ random error.

$M A I=\frac{V}{A g e}$

where: $\mathrm{MAI}=\left(\mathrm{m}^{2} \cdot \mathrm{ha}^{-1}\right.$ year $) ; \mathrm{V}=$ tree volume per hectare $\left(\mathrm{m}^{3} \cdot \mathrm{ha}^{-1}\right)$; Age ( in years).

\subsection{Model 3PG}

Model 3PG essentially estimates the amount of photo-synthetically active radiation absorbed by the canopy by Beer's law, considering it to be $50 \%$ of solar radiation. The model of the overall structure consists of five sub-models: (1) assimilation of carbohydrates, predicted by environmental modification of light efficiency use, assuming a constant radius of net primary production; (2) distribution of biomass in the leaves, root, and trunk, influenced by growing conditions and tree size ; (3) mortality of trees in the plot; (4) forest management (leaf area index of the canopy, basal area, plot volume, diameter at breast height (DBH), mean annual volume increase and (5) water balance in the soil, where evaporation is calculated using the PenmanMonteith model. A complete description of the growth model used can be found in the work of Landsberg and Waring (1997).

Parameterization was performed based on information supplied by the company and fertigation experiments in Eucalyptus grandis clones conducted by Silva (2006) for the same locations studied in this work. The following data were assessed: soil data, such as fertility rate, soil texture and maximum water availability in each locality; plant data, such as initial leaf, wood, and root biomass, obtained separately, based on the total fresh and sample weight, dried in oven at $65^{\circ} \mathrm{C}$ to obtain posterior dry weight; and physiological, such as quantic efficiency and maximum stomatal conductance of the canopy, using a portable infrared gas analyzer, model LC-PRO (ADC, Hoddesdon, UK) with source coupled light, fixed at $1500 \mathrm{mmol} \mathrm{m}^{-2} \mathrm{~s}^{-1}$ and ambient atmospheric concentration, stabilized by a buffer system.

Once parameterized, the main input variables required by model 3PG for the simulations were: climate data collected at the weather stations, using the monthly means of maximum and minimum air temperature $\left({ }^{\circ} \mathrm{C}\right)$, global solar radiation $\left(\mathrm{MJ} \mathrm{m}^{-2}\right.$ day $\left.^{-1}\right)$, rainfall $(\mathrm{mm})$, vapor pressure (mbar) and frost days (number of days month ${ }^{-1}$ ); Site data, such as latitude, soil class, fertility, soil water retention capacity; and plant data, such as tree population, and allometric relationships obtained through the forest inventory.

The Tukey test ( $95 \%$ confidence interval) was used to evaluate the differences of measured LAI response and other variables obtained from the inventory as well as those estimated by the model on the exposure surfaces evaluated.

\section{RESULTS}

The percentages of global radiation correction at inclined sites, compared to those measured at plane sites, in each exposure surface (Figure 2), showed that the northern surfaces had winter gains of up to $22 \%$ and summer losses of around $10 \%$. These values are close at both locations studied. The variations found in the southern surfaces reached 43 and $66 \%$ of radiation loss for the $\mathrm{AD}$ and $\mathrm{BO}$ plots, respectively, in the winter, and gains near $15 \%$ in the summer, for both locations.

The measured LAI data and those estimated by the 3PG model show higher values in the northern surface plots, with measured values equal to 3.26 and 1.71 ,

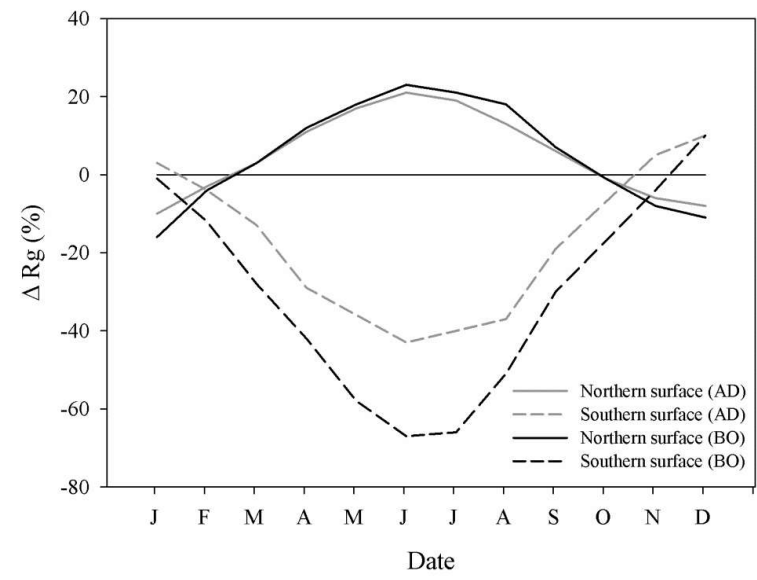

Figure 2 - Variation of the percentage difference of global solar radiation $(\Delta \mathrm{Rg})$ corrected according to the northern and southern surfaces for the stands located in Antonio Dias (AD) and Belo Oriente (BO).

Figura 2 - Variação da diferença percentual da radiação solar global ( $\Delta R g$ ) corrigida de acordo com as faces norte e sul, dos talhões localizados nas localidades de Antônio Dias (AD) e Belo Oriente (BO).

Revista Árvore, Viçosa-MG, v.40, n.2, p.319-327, 2016 
and equal to 2.44 and 1.58 in the southern surface in the AD and BO locations, respectively (Figure 3a), but significant $(p<0.05)$ only in AD. In both locations, the northern surface presented higher LAI estimated by the 3PG model than the southern surface in almost all the monthly series of the planting cycle (Figures $3 \mathrm{~b}$ and $3 \mathrm{c})$.

The wood and MAI volume measured was found to be higher in the northern exposure surface than in the southern surface (Figure 4a), in both locations, following the tendency verified in the LAI. This difference was found to be significant only in the volume data. Wood volume was 95.8 and $82.7 \mathrm{~m} 3$ ha- 1 in the AD location, and 107.7 and $78.6 \mathrm{~m} 3 \mathrm{ha}-1$ in the BO location, in the northern and southern surfaces, respectively. The data simulated by the model corroborate with the measured data, showing higher estimates in the northern surface. The estimated variables expressing wood production were slightly higher in $\mathrm{BO}$ (Figures $4 \mathrm{~b}$ and $4 \mathrm{c}$ ), presenting an MAI increase in relation to the AD location at the end of the evaluation period, of 11.9 and $13.4 \%$ and of volume of 11.4 and $12.9 \%$ in the northern and southern exposure surfaces, respectively.

\section{DISCUSSION}

The results show that locations with characteristics similar to the areas assessed in this study tend to present a climatic variation, determined by the difference imposed by physiography. Plants respond to different levels of variation, both at a microclimate scale imposed by declivity and relief exposure surface, and at a macro level, based on analysis of the climate defined by the different altitudes. These differences lead to specific patterns of forest growth, culminating in a differentiated productivity throughout the cycle, stressing the importance of understanding these eco-physiological interactions.

The greatest loss observed in the southern surfaces was due to the geographic location of the study sites, when the sun is positioned north for most part of the year, consequently leading to lower energy availability in the southern surfaces. This result may also be related to a greater difference in the degree of inclination between both locations.

Practically no differences were verified in the magnitude of the radiation gains between the northern surfaces in both locations of the stands, since the
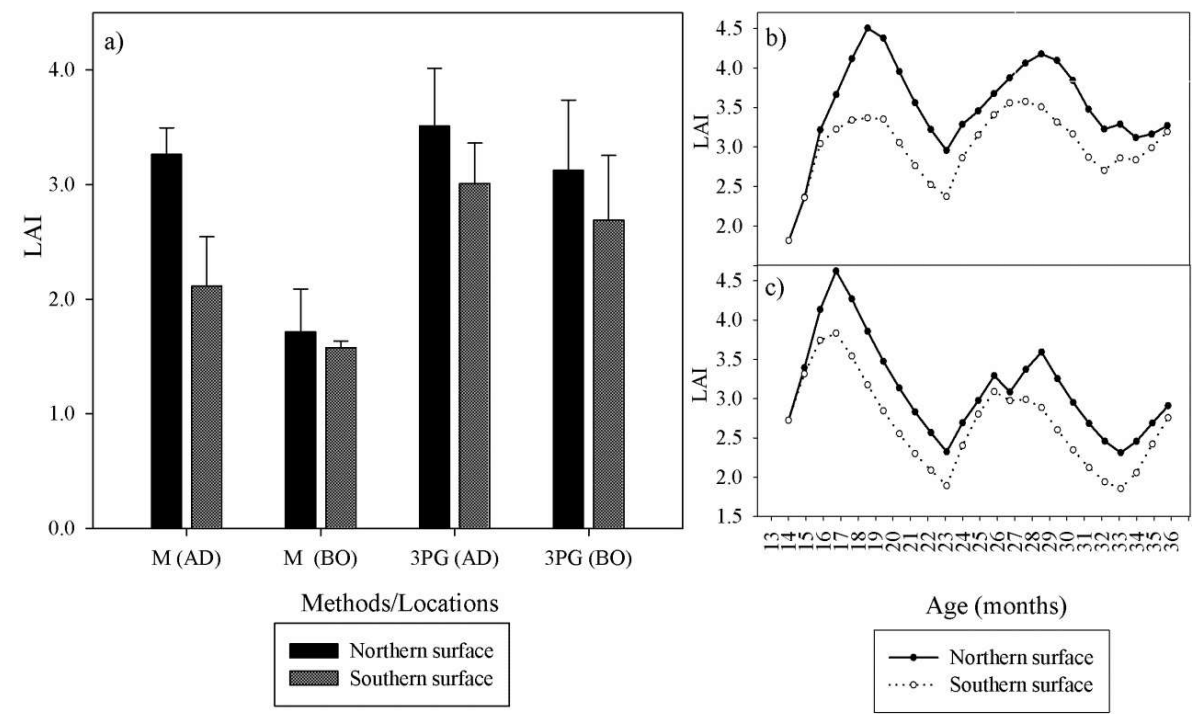

Figure 3 - a) LAI data measured (M) and estimated by the model 3PG in the northern and southern surfaces in Antonio Dias (AD) and Belo Oriente (BO). LAI monthly variation estimated by the model during the planting cycle in $\mathrm{AD}(\mathrm{b})$ and $\mathrm{BO}(\mathrm{c})$.

Figura 3 - a) Dados de IAF medidos (M) e estimados pelo modelo $3 P$ G nas faces norte e sul nas localidades de Antônio Dias (AD) e Belo Oriente (BO). Variação mensal do IAF estimado pelo modelo durante o ciclo de plantio em Antônio Dias (b) e Belo Oriente (c).

Revista Árvore, Viçosa-MG, v.40, n.2, p.319-327, 2016 


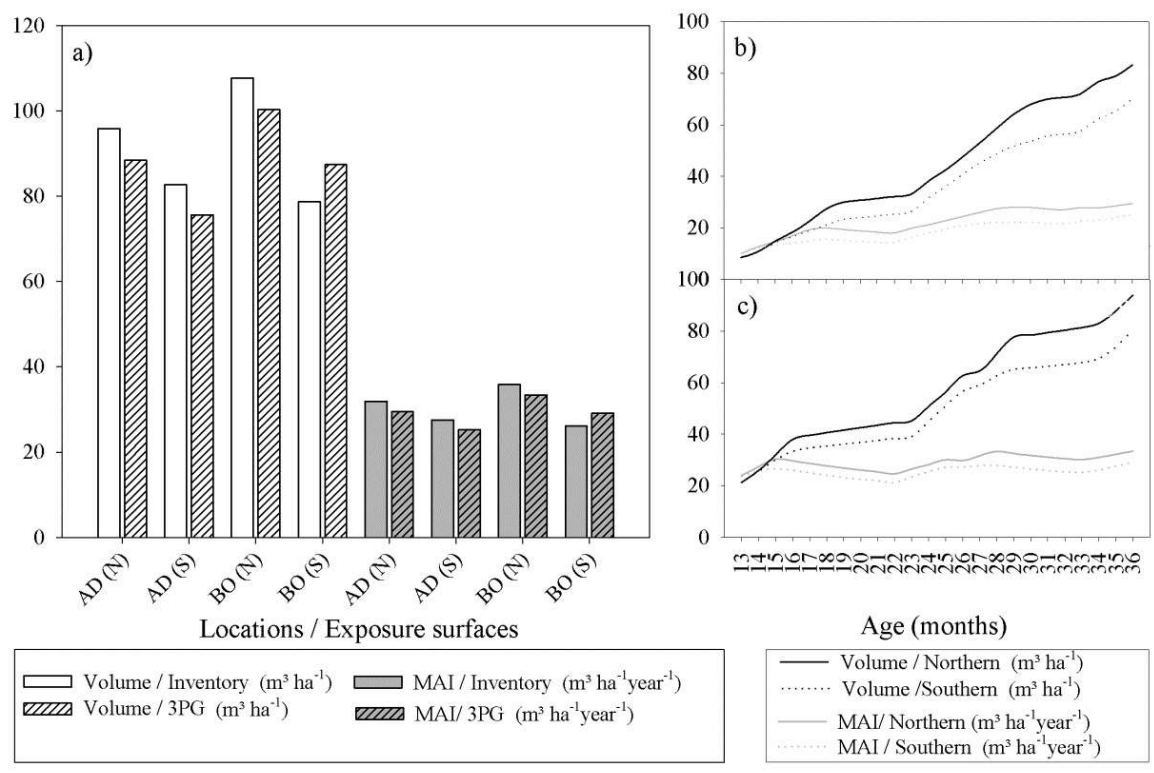

Figure 4 - (a) Volume data (V) and mean annual increment (MAI), measured and estimated by the model 3PG in the northern (N) and southern (S) exposure surfaces, as well as monthly series of these variables estimated by the model in (b) $\mathrm{AD}$ and (c) $\mathrm{BO}$, at the age of 32 months.

Figura 4 - (a) Dados de Volume (V) e incremento médio anual (IMA) mensurados e estimados pelo modelo $3 P G$ nas faces de exposição norte ( $N$ ) e sul (S) e série mensal destas variáveis estimadas pelo modelo nas localidades de (b) $A D$ e (c) BO em idade de 32 meses.

difference in declivity between the locations was of only one degree. This response pattern was also observed by Facco et al., (2009) in a micro-basin with undulated relief located in the Rio Doce basin.

The observed and simulated LAI differences between the northern and southern surfaces can be best explained by the magnitude of loss of solar radiation in the winter, when lower availability of energy and photons is observed for photosynthesis, compared to the summer radiation gain. Duz et al. (2004) found that, for tree species of the Atlantic forest, photosynthetic capacity, expressed through the net assimilation rate, increased irradiance from 2 up to $30 \%$. Declivity was found to be higher in the southern surfaces, compared to the northern surfaces of each location, thus being possible to infer that the loss in winter may be more decisive for a LAI reduction, a result enhanced in areas of lower altitude. Biomass incorporation by the plant depends on the integration of the leaf responses and radiation distribution in these elements. For this reason, global irradiation is a climatic variable of great importance in forest productivity, ecological, and hydrological models.
The leaf gain observed in the AD stands can affect the lower biomass allocation for wood at this initial stage of the cycle, since these are competing processes. At the end of the cycle, with the LAI tendency to reduce, this value can be increased, as measured by Souza et al. (2006), who found that the periodic increase in volume during the final years of the cycle in inventories carried out in $\mathrm{BO}$ was lower than in AD .

There was a delay in the simulated LAI increase response regarding the wettest months with peaks near the month of March for both stands. This behavior may be due to the soil water storage condition, where, despite decreased rainfall, the water remains available to the plant during subsequent periods.

Both locations have a good water supply, but BO has a higher evapotranspiration demand with higher temperatures and water deficits during the year, due to its lower altitude. Silva et al. (2013) found higher transpiration values in $\mathrm{BO}$, compared to $\mathrm{AD}$. It should be noted that most diffuse radiation due to higher cloudiness in AD may provide a better use of sunlight through the leaves, because of their multi-directional character,

Revista Árvore, Viçosa-MG, v.40, n.2, p.319-327, 2016 
which may allow greater absorption of radiation by the canopy and increased photosynthetic rate and leaf production (MARTINEZ, 1978; PAPADAKIS et al., 2000).

Further studies must be carried out to verify whether the observed tendency is repeated. A possible effect of surface declivity with incidence of radiation at different locations with distinct latitudes could be examined to assess the influence of variation in the solar declination angle.

\section{CONCLUSION}

Differences were found in the intensity of radiation in both exposure surfaces evaluated when corrections attributed to physiographic variations of the stands were made. A greater radiation loss was verified in the southern surfaces, due to the geographical location of the study areas and higher degree of inclination, compared to the northern surfaces.

Higher LAI, volume, and MAI values were verified in the northern exposure surface in the data measured in the field and estimated by the 3PG model.

\section{REFERENCES}

ALLEN, R.G.; PEREIRA, L.S.; RAES, D.; SMITH, $M$. Crop evapotranspiration - Guidelines for computing crop water requirements. Rome: FAO, 1998. (FAO Irrigation and Drainage Paper, 56)

ALMEIDA, A.C.; SIGGINS, A.; BATISTA, T. R.; BEADLE, C.; FONSECA, S.; LOOS, R. Mapping the effect of spatial and temporal variation in climate and soils on Eucalyptus plantation production with 3-PG, a process-based growth model. Forest Ecology and Management, v.259, n.9, p.1730-1740, 2010.

BAESSO, R.C.E.; RIBEIRO, A.; SILVA, M. Impacto das mudanças climáticas na produtividade do eucalipto na localidade norte do Espírito Santo e sul da Bahia. Ciência Florestal, v.20, n.2, p.335-344, 2010

CARVALHO, D.A.; OLIVEIRA-FILHO, A. T.; BERG, E. V. D.; FONTES, M. A. L.; VILELA, E. A.; SÁ, J. J.G.; MARQUES, M; CARVALHO, W. A. C. Variações florísticas e estruturais do componente arbóreo de uma floresta ombrófila alto-montana às margens do rio Grande, Bocaina de Minas, MG, Brasil. Acta Botanica Brasílica, v.19, n.1, p.91-109, 2005.

DUZ, S.R.; SIMINSKI, A.; SANTOS, M.; PAULILO, M.T.S. Crescimento inicial de três espécies arbóreas da Floresta Atlântica em resposta à variação na quantidade de luz. Revista

Brasileira de Botanica, v.27, n.3, p.587-596, 2004.

FACCO, A.G.; RIBEIRO, A; SEDIYAMA, G. C.; LEITE, F. P.; BARROS, N. F. Saldo de radiação em plantios de eucalipto em áreas de relevo ondulado. Revista Árvore, v.33, n.3, p.471480, 2009.

IQBAL, M. Correlation of average diffuse and beam radiation with hours of bright sunshine. Solar Energy, v.23, n.2, p.169-173, 1979.

LANDSBERG, J.J.; WARING, R.H. A generalised model of forest productivity using simplified concepts of radiation-use efficiency, carbon balance and partitioning. Forest Ecology Manage, v.95, p.209-228, 1997.

LIMA, F.Z. Desenvolvimento e avaliação de modelos de irradiancia solar difusa para Viçosa - MG. 1996b. 68f. Dissertação (Mestrado em Meteorologia Agrícola) -

Universidade Federal de Viçosa, Viçosa, MG, 1999

MARTINEZ, G.P.F. Características climáticas de los invernadores de plástico. Madri: Instituto Nacional de Investigaciones Agrarias, 1978. (Hojas Técnicas, 19).

MEFTI, A.; BOUROUBI, M.Y.; ADANE, A. Generation of hourly solar radiation for inclined surfaces using monthly mean sunshine duration in Algeria. Energy Conversion and Management, v.44, n.19, p.3125-3141, 2003.

PAPADAKIS, G.; BRIASSOULIS, D.; SCARASCIA MUGNOZZA, G.; VOX, G.; FEUILLOLEY, P.; STOFFERS, J. A. Radiometric and thermal properties of, and testing methods for greenhouse covering materials. Journal of Agricultural Engineering Research, v.77, n.1, p.7-38, 2000. 
PAUL, K.I; BOOTH, T. H.; JOVANOVIC, T.; SANDS, P. J.; MORRIS, J. D. Calibration of the forest growth model 3-PG to eucalypt plantations growing in low rainfall regions of Australia.

Forest Ecology and Management, v.243, p.237-247, 2007.

PENMAN, H.L. Evaporation, transpiration and evapotranspiration. In: PENMAN, H.L.

Vegetation and hydrology. Farnham Royal: Comm. Agric. Bureaux; 1963.

RODRÍGUEZ, R; REAL, P.; ESPINOSA, M.; PERRY, D. A. A process-based model to evaluate site quality for Eucalyptus nitensin the Bio-Bio Region of Chile. Forestry, v.82, n.2, p.149-162, 2009.

SARIYILDIZ, T.; KUCUK, A.M. Effects of tree species and topography on soil chemistry, litter quality, and decomposition in Northeast Turkey. Soil Biology \& Biochemistry, v.37, p.1695-1706, 2005.

SHERMAN, R.E.; MARTIN, P.H.; DEGLORIA, S.D. Fire and vegetation dynamics in high-elevation neotropical montane forests of the Dominican Republic. Ambio, v.37, n.7-8, p.535-541, 2008.

SIDARI, M; RONZELLO, G.; VECCHIO, G.; MUSCOLO, A. Influence of slope aspects on soil chemical and biochemical properties in a Pinus laricio forest ecosystem of Aspromonte (Southern Italy). European Journal of Soil

Biology, v.44, p.364-372, 2008
SILVA, G.G.C. Nutrição, crescimento e sua modelagem em povoamentos de eucalipto em resposta à disponibilidade de água e nutrientes. 2006.116f. Dissertação (Mestrado em Solos e Nutrição de Plantas) - Universidade Federal de Viçosa, Viçosa, MG, 2006.

SILVA, W.C.M; RIBEIRO, A.; NEVES, J. C L.; BARROS, N. F.; LEITE, F. P. Water balance model and eucalyptus growth simulation in the Rio Doce Basin, Brazil. Acta Scientiarum, v.35, n.4, p.403-412, 2013.

SOUZA, M.J.H.; RIBEIRO, A.; LEITE, H. G.; LEITE, F. P.; MINUZZI, R. B. Relação entre disponibilidade hídrica e produtividade do eucalipto em diferentes idades, em Guanhães, Minas Gerais. Revista Brasileira de Engenharia Agrícola e Ambiental, v. 10, p.629-638, 2006.

VEGA-NIEVA, D.J.; TOMÉ, M.; FONTES, L.; SOARES, P.; ORTIZ, L.; BASURCO, F.; RODRÍGEZ-SOALLEIRO, R. Developing a general method for the estimation of the fertility rating parameter of the 3-PG model: application in Eucalyptus globulus plantations in northwestern Spain. Canadian Journal of Forest Research, v.43, n.7, p.627-636, 2013

WATSON, D.J. Comparative physiological studies on growth of field crops: I. Variation in net assimilation rate and leaf area between species and varieties, and within and between years. Annals of Botany, v. 11, p.41-76, 1947. 